\title{
MENINGKATKAN HASIL BELAJAR SISWA DENGAN MENGGUNAKAN MODEL KOOPERATIF TIPE STAD PADA PEAJARAN IPS DI KELAS IV SD NEGERI 101775 SAMPALI
}

\author{
Herawati Bukit
}

Surel: herawatybukit@gmail.com

\begin{abstract}
ABSTRAK
Masalah yang diteliti dalam penelitian ini adalah rendanya hasil belajar siswa pada mata pelajaran IPS. Tujuan penelitian ini adalah untuk Meningkatkan Hasil Belajar Siswa Dengan Menggunakan Model Kooperatif Tipe Student Teams Achievement Divisions (STAD) Pada Pelajaran IPS Materi Pokok Aktivitas Ekonomi Dan Sumber Daya Alam di Kelas IVA SD Negeri 101775 Sampali. Berdasarkan hasil penelitian diperoleh pada kondidi awal atau sebelum diberi tindakan terdapat 22 siswa $(78,57 \%)$ yang belum tutas belajar, 6 siswa $(21,43 \%)$ yang tuntas dengan nilai rata- rata 51,25. Pada siklus I terdapat 13 siswa $(46,43 \%)$ yang belum tuntas, 15 siswa $(53,57 \%)$ yang sudah tuntas dengan nilai rata- rata 67 , dan pada siklus II terjadi peningkatan yaitu 25 siswa $(89,3 \%)$ yang tuntas belajar, 3 siswa $(10,7 \%)$ yang belum tuntas belajar dengan nilai rata- rata 80,35.
\end{abstract}

Kata kunci : Metode STAD, Hasil belajar siswa

\section{PENDAHULUAN}

Pendidikan merupakan suatu proses pengembangan diri individu dari kepribadian seseorang yang dilakukan secara sadar dan penuh tanggung jawab untuk dapat meningkatkan pengetahuan, keterampilan dan sikap serta nilainilai sehingga mampu menyesuaikan diri dengan lingkungan. Dalam UU Republik Indonesia No 20 Tahun 2003 tentang sistem pendidikan nasional dijelaskan bahwa Pendidikan Nasional bertujuan untuk mengembangkan potensi peserta didik agar menjadi manusia yang beriman dan bertaqwa kepada Tuhan Yang Maha Esa, beraklak mulia, sehat, berilmu, cakap, kreatif, mandiri, dan menjadi warga negara yang demokratis serta bertanggung jawab. Salah satu indikator pendidikan yang berkualitas adalah perolehan hasil belajar siswa di sekolah, dimana kualitas pendidikan yang baik merupakan tujuan dari pendidikan itu sendiri.

IPS merupakan salah satu pelajaran di sekolah dasar yang di nilai cukup memegang peran penting. Karena pelajaran IPS di Sekolah Dasar memberikan pengetahuan dasar tentang ilmu sosial dan keterampilan sebagai media pelatihan bagi warga negara. Selain itu pendidikan IPS tidak hanya memberikan ilmu pengetahuan semata, tetapi harus berorientasi pada perkembangan keterampilan berfikir 

kritis, sikap, dan berkenyataan pada hidup sosial siswa.

Berdasarkan pernyataan di
atas Peneliti tertarik untuk mengetahui bagaimana sebenarrnya pembelajaran IPS di Sekolah Dasar. Oleh karena itu berdasarkan hasil Observasi yang peneliti lakukan di SD Negeri 101775 Sampali, khususnya pembelajaran IPS, menunjukkan hasil belajar siswa masih rendah. Hal ini terlihat pada nilai rata-rata ulangan harian yang relatif rendah. Nilai rata- rata yang diperoleh siswa adalah 68, sementara KKM (Kriteria Ketuntasan Minimal) adalah 70. Dari 28 siswa hanya 10 siswa yang mencapai KKM dengan presentasi 36\%, sedangkan 18 Siswa belum mencapai KKM dengan presentasi $64 \%$. Dari data tersebut dapat disimpulkan bahwa kurangnya penguasaan siswa dalam pembelajaran IPS pada pokok bahasan "Aktivitas Ekonomi Dan Sumber Daya Alam" menunjukan hasil belajar yang masih rendah.

Selain itu proses pembelajaran hanya berpusat pada guru, guru masih lebih dominan menggunakan metode ceramah. Masalah selanjutnya yang terlihat dalam pembelajaran IPS adalah kurangnya kreatifan siswa dalam proses pembelajaran hal ini disebabkan karena guru menjelaskan materi pembelajaran sementara siswa hanya duduk diam dan mendengarkan, sehingga membuat siswa tidak banyak terlibat baik dari berfikir maupun bertindak.Masalah yang terlihat adalah kurangnya minat belajar siswa pada pelajaran IPS.

Salah satu upaya yang dapat dilakukan oleh peneliti untuk mengatasi masalah- masalah yang terdapat dalam pelajaran IPS adalah dengan menggunakan model Student Teams Achievement Divisions $(S T A D)$. Proses pembelajaran yang lebih dominan oleh keaktifan siswa dalam diskusi kelompok-kelompok kecil yang terdiri dari 4-5 orang secara heterogen, tidak membedabedakan teman sekelompoknyadan tugas guru membimbing siswa dalam kelompok. Dengan begini proses pembelajaran yang pada akhirnya diharapkan dapat meningkatkan pemahaman dan hasil belajar siswa.

Berdasarkan permasalahan yang telah diuraikan pada latar belakang di atas, maka yang menjadi rumusan masalah dalam penelitian ini adalah : Apakah dengan modeL kooperatif tipe Student Teams Achievement Divisions (STAD) dapat meningkatkan hasil belajar IPS materi aktivitas ekonomi dan sumber daya alam pada siswa kelas IV SD Negeri 101775 Sampali T.A 2015/2016.

\section{METODE PENELITIAN}

Jenis penelitian ini termasuk jenis penelitian tindakan kelas (Classroom Action Research). Pemilihan jenis penelitian ini merupakan upaya dalam meningkatkan efektivitas pembelajaran yang berlangsung dalam tahapan/siklus. Melalui 
penelitian tindakan kelas ini diharapkan permasalahan pembelajaran dapat dikaji, ditingkatkan dan dituntaskan, sehingga proses pembelajaran menjadi inovatif dan hasil belajar lebih dapat diwujudkan secara sistematis.

Penelitian ini dilakukan di SD Negeri 101775 Sampali kecamatan Percut Sei Tuan. Waktu penelitian di lakukan pada semester genap tahun ajaran 2015/2016 selama 2 bulan.

Subjek dalam penelitian tindakan kelas ini adalah siswa kelas IVA di SD Negeri 101775 Sampali Kecamatan Percut Sei Tuan Tahun Ajaran 2015/2016 yang berjumlah 28 orang yang terdiri dari 15 laki- laki, dan 13 orang perempuan.

Objek penelitian ini adalah hasil belajar IPS siswa kelas IVA SD Negeri 101775 Sampali Kecamatan Percut Sei Tuan, penerapan model Team Achievement Division (STAD) sebagai upaya untuk meningkatkan hasil belajar siswa pada pelajaran IPS kelas IVA materi pokok Aktivitas Ekonomi dan Sumber Daya Alam.

Pelaksanaan Penelitian Tindakan Kelas ini dilaksanakan dalam dua siklus. Setiap siklus meliputi perencanaan, tindakan, observasi dan refleksi.

Prosedur Penelitian Tindakan Kelas ini meliputi tahap perencanaan, tindakan, observasi dan refleksi. Tahap tersebut disusun dalam dua siklus. Secara terperinci, langkahlangkah yang dilakukan dalam penelitian ini adalah sebagai berikut:
Siklus I

\section{Tahap Perencanaan}

a. Menyusun RPP

b. Menyiapkan sarana pembelajaran

c. Menyusun instrument penelitian

\section{Tahap Pelaksanaan}

Pada tahap ini kegiatan yang dilakukan adalah melaksanakan pembelajaran yang disesuaikan dengan rencana pelaksanaan pembelajaran ( RPP ) yang telah di susun menggunakan metode TSTS.

\section{Tahap Pengamatan}

Pengamatan atau observasi ditunjukkan kepada peserta didik untuk mengamati proses kegiatan belajar mengajar.

\section{Refleksi}

Tahap refleksi ini dilakukan berdasarkan data hasil observasi dan hasil evaluasi.

\section{Siklus II}

\section{Tahap Perencanaan}

Tahap perencanaan pada siklus dua meruakan rencana berdasarkan hasil refleksi pada siklus pertama.

\section{Tahap Pelaksanaan}

a. Guru menyampaikan kepada siswa tentang apa yang akan dilakukan dalam pembelajaran

b. Guru menjelaskan kembali tentang pelaksanaan STAD

c. Guru menerangkan apa saja kesalahan pada siklus 
sebelumnya dan mencoba memperbaikinya disiklus ini.

\section{Tahap Pengamatan}

Tahap ini sesuai dengan siklus I, observasi dilakukan untuk melihat perubahan yang terjadi pada siswa yang belajar.

\section{Refleksi}

Refleksi dilakukan pada akhir siklus II. Kegiatan ini dilakukan untuk melihat hasil perkembangan pelaksanaan dan membuat kesimpulan

\section{Teknik Pengumpulan Data}

Alat yang digunakan dalam pengumpulan data pada penelitian ini adalah tes dan observasi.

Tes

Tes adalah alat untuk memperoleh data tentang kemampuan para siswa dengan cara pemberian soal. Soal-soal yang diberikan sebanyak 10 butir soal dalam pilihan berganda

\section{Observasi}

Observasi dilakukan pada tahap pengamatan.

\section{Tekhnik Analis data}

Analisis data dalam peneitian ini dilakukan dengan mengetahui berhasil atau tidaknya tindakan yang sudah dilakukan. Analisis penelitian data yang akan dilakukan adalah kualitatif dan kuantitatif. Data kualitatif berupa pengisian data observasi terhadap pelaksanaan pembelajaran yang dilakukan oleh guru dan peneliti. Data kuantitatif dengan mengadakan (tes awal, post tes siklus I dan post tes siklus II).

Untuk menekankan kemungkinan siswa membuat tebakan maka dalam aturan skoring menghitungkannya dengan mengenakan benda pada butir soal yang dijawab salah. Menurut Gronlund dan Linn(dalam Purwanto 2011: 190) untuk menyusun penskoran dengan denda digunakan rumus sebagai berikut:

a. Rumus untuk menentukan penskor $S=R-\frac{W}{N-1}$

Keterangan:

$\mathrm{S}=$ score (skor)

$\mathrm{R}=$ right (jumlah jawaban benar)

$\mathrm{W}=$ wrong (jumlah jawaban salah)

$\mathrm{N}=$ Option (jumlah pilihan jawaban).

b. Rumus menentukan ketuntasan belajar siswa

Untuk mengetahui ketuntasan belajar siswa secara individu dilihat dari nilai tes siswa. Siswa yang dikatakan tuntas adalah siswa yang dapat mencapai KKM yaitu 70 . Rumus yang digunakan untuk menghitung ketuntasan hasil belajar siswa secara perorangan adalah sebagai berikut:

$$
P H B=\frac{\text { Skor Perolehan }}{\text { Skor Maksimal }} x 100
$$


Herawati Bukit : Meningkatkan Hasil Belajar ...

c. Rumus yang digunakan untuk menghitung nilai rata- rata siswa adalah sebagai berikut: (Purwanto : 116)

$$
\overline{\mathrm{X}}=\frac{\sum X}{\sum N}
$$

d. Rumus yang dapat digunakan untuk menghitung ketuntasan belajar siswa secara klaskal adalah sebagai berikut:

$$
\begin{aligned}
& \text { PKK } \\
& =\frac{\sum \text { siswa yang tuntas belajar }}{\sum \text { siswa }} \times 100
\end{aligned}
$$

Dengan kriteria keberhasilan PKK: $80 \%$. Dengan kriteria dalam persen sebagai berikut :

$\begin{array}{ll}>80 \% & \text { : Sangat tinggi } \\ 60-79 \% & \text { : Tinggi } \\ 40-59 \% & \text { : Sedang } \\ 20-39 \% & \text { : Rendah } \\ <20 \% & \text { : Sangat rendah }\end{array}$

e. Analis Data Hasil Observasi

Penelitian tindakan kelas ini dikatakan berhasil jika nilai hasil observasi guru dan siswa $\geq 80$. Untuk menganalisis data hasil observasi yang dilakukan digunakan rumus sebagai berikut

$$
\text { N HO }=\frac{\text { jumlah skor Observasi }}{\text { jumlah skor Maksimal }} x 100
$$

Kreteria ketuntasan

$\begin{array}{ll}90-100 & : \text { sangat baik } \\ 80-89 & \text { : Baik } \\ 70-79 & \text { : Cukup } \\ <70 & \text { : Kurang }\end{array}$

\section{HASIL PENELITIAN DAN PEMBAHASAN}

\section{Hasil Penelitian}

Kemampuan siswa dalam mengusai materi Aktivitas Ekonomi Dan Sumber Daya Alam dengan nilai rata - rata kelas mencapai 51,25 dari 28 siswa terdapat $21,4 \%$ ) atau 6 orang siswa yang mendapat hasil belajar rendah ( belum tuntas ) dan ( $78,6 \%$ ) atau 22 orang siswa masuk dalam kategori tuntas belajar pada pokok bahasan q Persiapan Kemerdekaan Indonesia.aktivitas ekonomi dan sumber daya alam.

Berdasarkan rumus ketuntasan belajar siswa secara klasikal diperoleh :

$$
\begin{aligned}
& \mathrm{PPH}=\frac{22}{28} \times 100 \%=78,6 \%(\mathrm{~B} \mathrm{~T}) \\
& \mathrm{PPH}=\frac{6}{28} \times 100 \%=21,4 \%(\mathrm{~T})
\end{aligned}
$$

Berdasarkan tes hasil belajar diatas, peneliti melakukan perbaikan pembelajaran dengan melanjutkan pada tes siklus I, dan dalam pelaksanaan tindakan ini, peneliti yang bertindak sebagai guru dengan menggunakan model Student Team Achievement Divisions (STAD) dalam melaksanakan pembelajaran.

\section{Pelaksanaan Dan Hasil Penelitian Pada Siklus I \\ Perencanaan}

Penelitian ini melibatkan guru kelas sebagai pengamat sekaligus menjadi kolaborator yang secara bersama- sama dengan peneliti bertindak sebagai pengajar di dalam 
kelas. Guru bertugas melakukan pengamaatan, mecatat segala proses kegiatan yang terjadi di dalam kelas, dengan berpedoman pada lembar observasi kemudian hasilnya didikusikan bersama sebagai bahan masukan bagi perbaikan sebagai pelaksaan berikutnya.

Berdasarkan hasil pre test, maka dapat diketahui bahwa tingkat ketuntasan hasil belajar siswa masih rendah. Oleh karena itu peneliti merencanakan alternative dengan mempelajari kesulitan- kesulitan yang dihadapi siswa dengan menerapkan model pembelajaran Student Team Achievement Divisions (STAD) sebagai upaya yang dilakukan peneliti untuk memperbaiki proses belajar mengajar yang dilaksanakan adapun upaya yang dilakukan peneliti yaitu: a). Menyiapkan Rencana Pelaksanan Pembelajaran (RPP), b) Mempersiapkan bahan/model dan materi yang akan diajarkan oada materi Aktivitas Ekonomi dan Sumber Daya Alam, c). Membuat soal-soal tugas yang akan diberikan pada masing-masing siswa berdasarkan kompetensi dasar yang dipelajari, d) Membuat lembar observasi untuk melihat bagaimana perkembangan peneliti dalam penyampaian materi kepada peserta didik didalam kela, e) Menyusun tes untuk mengukur hasil belajar siswa selama tindakan penelitian diterapkan yaitu soal siklus post test siklus I.

\section{Pelaksanaan}

Pada kegiatan ini yang melaksanakan pembelajaran dengan menggunakan model Student Team Achievement Divisions (STAD) adalah peneliti. Materi yang akan diajarkan pada tindakan ini adalah Aktivitas Ekonomi dan Sumber Daya Alam.

\section{Pengamatan (Observasi)}

Observasi yang dilakukan oleh peneliti di kelas V SD Negeri 101775 Sampali, dengan tujuan menyesuaikan penerapan tindakan dengan skenario pembelajaran yang dirancang. Berdasarkan hasil pengamatan pada siklus I adalah guru dan siswa belum optimal dalam melaksanakan tindakan (proses belajar mengajar). Nilai hasil observasi guru pada siklus I 64,5 dan nilai hasil observasi siswa 64,3.

\section{Refleksi}

Pada akhir siklus I dilakukan refleksi terhadap seluruh materi yang telah diajarkan guru kepada siswa. Refleksi dilakukan pada akhir pertemuan siklus I setela semua materi diajarkan. Siswa diberikan test untuk mengetahui hasil- hasil yang diperoleh peneliti melalui model pembelajaran Student Team Achievement Divisions (STAD) dan juga untuk mengetahui tingkat pengguasaan siswa mengenai materi aktivitas ekonomi dan sumber daya alam di kelas IV A SD Negeri 101775 sampali.pada siklus I ini masih banyak siswa yang salah 
menjawab pertanyaan yang digunakan pada saat tes.

Hal ini disebabkan karena masih banyak siswa yang tidak memahami pelajaran yang dikutinya, padahal soal tes berdasarkan materi yang baru dijelaskan oleh peneliti. Data- data yang diperoleh pada siklus I ini kan dijadikan acuan untuk perbaikan pada siklus II untuk dapat meningkatkan pemahaman siswa tentang aktivitas ekonomi dan sumber daya alam sehingga hasil belajar siswa pada pelajaran IPS dapat meningkat

\section{Tabel Deskripsi Ketuntasan Hasil Belajar Siswa Pertemuan Siklus I}

\begin{tabular}{|c|c|c|c|c|}
\hline $\begin{array}{c}\text { N } \\
\text { o }\end{array}$ & $\begin{array}{c}\text { Jumlah } \\
\text { Siswa }\end{array}$ & $\begin{array}{c}\text { Jumlah } \\
\text { Nilai }\end{array}$ & $\begin{array}{c}\text { Persent } \\
\text { ase \% }\end{array}$ & K \\
\hline 1 & 1 & 90 & $3,57 \%$ & T \\
\hline 2 & 2 & 85 & $7,14 \%$ & T \\
\hline 3 & 3 & 80 & $10,7 \%$ & T \\
\hline 4 & 3 & 75 & $10,7 \%$ & T \\
\hline 5 & 6 & 70 & $21,4 \%$ & T \\
\hline 6 & 2 & 65 & 7,145 & B T \\
\hline 7 & 3 & 60 & $10,7 \%$ & B T \\
\hline 8 & 4 & 55 & $14,3 \%$ & B T \\
\hline 9 & 2 & 50 & $7,14 \%$ & B T \\
\hline 10 & 1 & 45 & $3,57 \%$ & B T \\
\hline \multicolumn{2}{|c|}{ Jumlah } & & $100 \%$ & \\
Siswa : 28 & & & \\
\hline
\end{tabular}

Dari tabel di atas menunjukkan bbahwa kemampuan siswa dalam mengusai materi Aktivitas Ekonomi dan Sumber Daya Alam pada siklus I dengan nilai rata - rata kelas mencapai 67 dari 28 siswa terdapat $(46,43 \%)$ atau 13 orang siswa yang mendapat hasil belajar rendah ( belum tuntas ) dan
$(53,57 \%)$ atau 15 orang siswa masuk dalam kategori tuntas belajar pada pokok bahasan aktivitas ekonomi dan sumber daya alam.

\section{Pelaksanaan dan Hasil Siklus II Perencanaan Tindakan}

Berdasarkan hasil post test siklus I, maka dapat diketahui bahwa tingkat ketuntasan hasil belajar siswa masih rendah. Oleh karena itu peneliti merencanakan alternative dengan mempelajari kesulitankesulitan yang dihadapi siswa dengan menerapkan model pembelajaran Student Team Achievement Divisions (STAD) sebagai upaya yang dilakukan peneliti untuk memperbaiki proses belajar mengajar yang dilaksanakan adapun upaya yang dilakukan peneliti sama seperti siklus I disini hanya berbeda dengan system pembelajaran dan bimbingan kempolok.

\section{Pelaksanaan Tindakan}

Pada siklus II ini, peneliti melaksanakan kegiatan pembelajran berdasarkan pengembangan rencana pelaksanaan pembelajaran yang telah disusun dengan menggunakan model pembelajaran Student Team Achievement Divisions (STAD). Kegiatan ini untuk mengoptimalkan kegiatan yang belum terlakasana dengan baik pada pembelajaran siklus I. pada siklus II terdiri dari $2 \mathrm{x}$ pertemuan yaitu pertemuan I dan peremuan II. Pada siklus II ini terdapat 25 orang siswa $(89,3 \%)$ yang sudah tuntas dan 3 orang siswa $(10,7 \%)$ yang belum tuntas dengan 
nilai rata- rata 80,35 . Pada siklus II ini sudah dikatakan ketuntasan klasikan mencapai secara maksimal $80 \%$. Dan pada siklus II sudah dikatakan semua siswa sudah memahami materi aktivitas ekonomi dan sumber daya alam.

\section{Observasi}

Observesi memberikan hasil kemampuan peneliti dalam menyampaikan aktivitas ekonomi dan sumber daya alam dengan menerapkan model Student Team achievement Divisions (STAD) dapat dilihat pada hasil nilai observasi guru 87,5 sedangkan hasil nilai observasi siswa 92,85 .

\section{Refleksi}

Upaya - upaya yang telah dilakukan pada pembelajaran IPS pada siklus II terjadi peningkatan. Dapat dilihat hasil belajar siswa secara klasikal sebanyak 25 siswa( $89,3 \%$ ) sudah mencapai ketuntasan hasil belajar.

Dengan melihat tes hasil belajar siklus II ini, diketahui bahwa siswa telah mencapai ketuntasan belajar klasikal. Sehingga tidak perlu melakukan tindakan pembelajaran ke siklus berikutnya.

\section{Pembahasan Hasil Penelitian}

Berdasarkan hasil dan pembahasan selama pelaksanaan penelitian di SD Negeri 101775 Sampali maka dapat dketahui bahwa dengan menggunakan model kooperatif tipe Student Team Achievement Divisiont (STAD) pada pelajaran IPS materi aktivitas ekonomi dan sumber daya alam

Berdasarkan dari table di atas bahwa pencapaian hasil belajar pada saat test awal sebanyak 6 siswa atau $21,43 \%$ yang tuntas dengan nilai rata- rata kelas 51,25. Pada siklus I jumlah siswa yang tuntas 15 siswa atau 53,57\% dengan nilai rata- rata 67 , sedangkan pada siklus II jumlah siswa yang tuntas meningkat yaitu 25 siswa atau $89,3 \%$ dengan nilai ratarata 80,35 .

\section{SIMPULAN}

Berdasarkan hasil penelitian yang telah diperoleh maka dapat ditarik kesimpulan dari penelitian ini adalah:

a. Pembelajaran dengan menggunakan model Student Team Achievement Divisions (STAD) pada pembelajaran IPS materi pokok Aktivitas Ekonomi dan Sumber Daya Alam dapat meningkatkan hasil belajar siswa di kelas IV SD Negeri 101775 Sampali Tahun Ajaran 2015/2016.

b. Sebelum pelaksanaan tindakan, terlebih dahulu dilakukan tes awal. Dari nilai tes awal sebanyak 22 orang siswa $(78,57 \%)$ yang belum tuntas dalam belajar dan 6 orang siswa $(21,43 \%)$ yang telah mencapai standat ketuntasan belajar.

c. Setelah pelaksanaan siklus I dengan menggunakan model kooperatif Student Team Achievement Divisions (STAD) 
terdapat sebanyak 13 orang siswa $(46,43 \%)$ yang belum tuntas dan sebanyak 15 Orang siswa $(53,57 \%)$ yang mencapai ketuntasan.

d. Setelah pelaksanaan siklus II dengan menggunakan model kooperatif Student Team Achievement Divisions (STAD) terdapat sebanyak 3 orang siswa $(10,7 \%)$ yang belum tuntas belajar dan sebanyak 25 orang siswa $(89,3 \%)$ yang mencapai ketuntasan belajar siswa.

e. Bahwa dengan adanya model kooperatif Student Team Achievement Divisions (STAD)yang diterapkan oleh guru, maka siswa tersebut terlatih dan juga terbiasa dalam mengerjakan soal- soal khususnya pada materi pokok aktivitas ekonomi dan sumber daya alam.

\section{DAFTAR RUJUKAN}

Arikunto, 2008. Dasar-Dasar Evaluasi pendidikan. Bumi Aksara: Jakarta

Arikunto, 2014. Penelitian Tindakan kelas. Bumi Aksara: Jakarta.

Aqib, Zainal. 2010. Penelitian Tindakan Kelas . Bandung : Yrama Widya

Djamarah, 2011. Psikologi Belajar. Rineka Cipta: Jakarta.

Huda miftahul, 2014. Model-Model Pengajaran dan Pembelajaran. Pustaka Belajar: Yogyakarta.

Istarani, 2012. 58Model

Pembelajaran Inovatif. Media Persada: Medan
Khairani, 2013. Psikologi Belajar. Aswaja Pressindo: Yogyakarta.

Purwanto, 2011. Evaluasi Hasil Belajar. Pustaka Pelajar: Surakarta.

Sardiman, 2008. Interaksi dan Motivasi Belajar mengajar. Raja Grapindo Prasada: Jakarta

Shoimin, 2014. 68Model Pembelajaran Inovatif Dalam Kurikulum 2013. Ar-ru Media: Yogyakarta.

Slameto, 2013. Belajar dan FaktorFaktor Yang Mempengaruhi. Rineka Cipta: Jakarta Slavin, 2015. Cooperative Learning. Nusa Media: Bandung.

Trianto, 2011. Mendesain Model Pembelajaran Inovatif Progesif. Prenada Media Group: Jakarta 